\title{
Evolution, Transformation, and Representation in Buddhist Architecture The Square Shrines of Buddhist Monasteries in Central Asia after the Fourth Century
}

\section{Young Jae Kim and Dong Soo Han}

Part-time Lecturer, Ph.D. (History and Theory of Architecture), School of Architecture, Hanyang University, Seoul, Korea Associate Professor, School of Architecture, Hanyang University, Seoul, Korea

\begin{abstract}
This study notices that all religions in Central Asia from the fourth century through seventh century C.E. provided considerable hands in keeping a uniform unity through a process of assimilation, although art and architecture were greatly stimulated by the creative genius of the many people. The study thus intends to argue that the common ideas of rituals and primitive forms of religious shrines lead the square-based layout of Buddhist shrines the unity and universality in the architectural products of particular regions or epochs: i.e. the "square-based plan" in Buddhist temples of Central Asia was a significant prototype in the synthesis with pre-Buddhist architectural models and Buddhist universal ideas. Thus, this thesis notes that they did not lose the universal principles of the Buddhist shrine plans due to ritual functions, and even there have been never differences from pre-Buddhist building models remarked by the periods and the venues in which they were produced, although there had been continuous evolutions and adaptive transformations in the local tastes of religious architecture. Accordingly, this study discusses how such plans in Buddhist architecture had been consistently produced within that regional style also representative of the local idioms of architecture, and how they were adopted in the sites, founded on the composition of ritual functions. The foreign architectural cultures were selectively chosen getting along with local building types of each site according to each taste for architecture as a result.
\end{abstract}

\section{Keywords: Central Asia, Buddhist Monastery (Temple), Zoroastrian Temple, Nabataean Temple}

\section{INTRODUCTION}

Despite the long distance between Eastern Asia, Central Asia, and South Asia, there had been considerable similarities in cultural patterns and building forms. It is why they have had a same cultural sphere, called Silk Road, ${ }^{1}$ which had bound different cultural

\footnotetext{
${ }^{1}$ The modern terminology of "Silk Road" is English translation of German Seiden Strassen, which was used for the first time by Ferdinand von Richthofen (18331905). In the second century B.C.E. the Silk Roads had been the most critical channels for cultural exchange between the East and the West. The transmission was launched from northwestern India to Pakistan, Afghanistan, Central Asia, Xinjiang (新疆, Chinese Turkistan), China, Korea and Japan. Most maps depict the Silk Road as departing from Xian in China, though most of China's silk was produced further south (Frances Wood, 2002: Chapter 1). From Xian(西安), the Silk Road ran westwards through Lanzhou (蘭州), then through the Gansu (甘 肅) corridor to Dunhuang (敦煌). Near Dunhuang, the desert routes split. The main northern route followed the southern edge of the Tian Shan mountains,

Corresponding Author: Young Jae KIM, Part-Time Lecturer School of Architecture, Hanyang University 222, Wangshimni-ro, Seongdong-gu, Seoul 133-791, South Korea

Tel : +82 207088725788 e-mail : kyjwow@empal.com
}

This is an Open Access article distributed under the terms of the Creative Commons Attribution Non-Commercial License (http://creativecommons. org/licenses/by-nc/3.0/) which permits unrestricted non-commercial use, distribution, and reproduction in any medium, provided the original work is properly cited. realms. Under mutual exchanges on new information between each area, existing building constructions within them were obviously combined with new architectural forms and techniques, and advanced considerably according to the need of the times. Also, so far most studies have been considerably separated from the site where the statues and the murals were originally placed at the early time. In the study of Buddhist monasteries, what we intent to tell are that the spatial composition of the monastery is closely related to the site (built-environment), built-icons like statues, and wall paintings. In other words, in the most necessary studies to us, it is even more significant to reflect the original context shown from both sites and legacies than to appreciate their own relics exhibited in the museum, because the plan of shrines and the manners of enshrinement in the monasteries played critical roles in deciding the characteristics of the building.

According to the need and willingness of Buddhists, likewise, the plans of shrine and the placement of statues and murals

running along the north of the Taklamakan desert and passed through the oasis towns of Hami(哈密), Turfan(車師前王廷, Gaochang高昌), Karashahr(焉者), Korla(危須), Kucha(龜茲), Aksu(姑墨), and Uch-turfan (溫宿) before reaching Kashgar (疎勒). This route, called Tianshannanlu(天山南路, or Xiyubeidao 西域 北道) more arduous than the southern route, came into its own in the late fourth century. Also, this northern route crosses the west over the Congling(Pamirs), and emerges into Dayuan(Ferghana), Kangju(Tashkent plus the Chu, Talas, and middle Jaxartes basins), and Yancai (the Alans). Whereas, the southern route, called Xīyunandao(西域南道), ran through the oases of Shanshan(Charklik, 鄯善, Loulan), Cherchen(且末), Niya(尼壤), Keriya(拘彌), Khotan(Heitian, 干闑) and Yarkand(沙車), Tashkurghan(蒲犁), and ended in Kashgar(疎勒). (Fig. 1) 


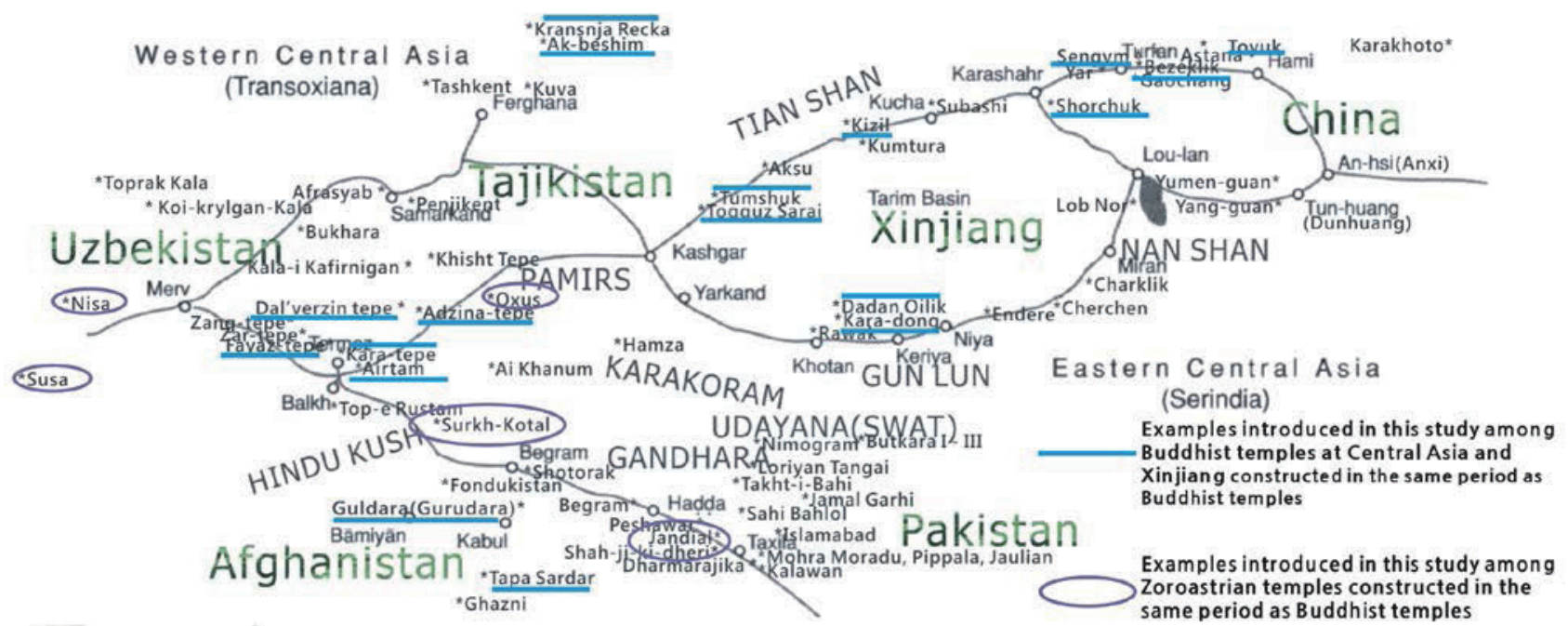

Figure 1. Buddhist Temples in Central Asia (vis-à-vis Gandharan and Zoroastrian temples)

have been in the same way represented for Buddhist times of the regions. These same tendencies in Buddhist monasteries have been closely related with a cosmopolitan social and spiritual climate of Central Asia, open to influences from all directions. So, Buddhism could play a role of an intermediary force. Likewise, along the Silk Road from Gandhara, the layouts of monasteries had been consistently preserved in "geometric square plans" caused by preBuddhist architectural models and Buddhist ideas. They had many transformations under the influences on other religious factors depending on residential buildings of each locales sharing historical climate of each area, doctrinal tastes of sectarian Buddhists, and such other religions constructions as Zoroastrian and Nabataean temples.

My argument is that the "square plans" in the territories of Central Asia (Afghanistan, Uzbekistan, Tajikistan, and Xinjiang), which territories were intimately connected through the various paths of the Silk Route, did not only accept ritual functions drawing upon religious behaviors for the pradakshina patha ${ }^{2}$ as an integral part of the pilgrimage activity, but also local and foreign architectural traditions such as Zoroastrian temples and Nabataean(Syrian) monuments and houses. Therefore, through the qualitative analysis depending on the layout of the sanctums with perfect drawings in all Central Asian Buddhist temples (Fayaz Tepa, Guldara, Kara Tepe, Tapa Sardar, Dalverzin-tepe, Adzina Tepe, Airtam I \& II, AkBeshim I \& II, Krasnorechensk I \& II, partially adding the square shrines of Xinjiang such as Karadong(n.61), Dada Oilik(D12), Kizil(n.38), Shorchuk(F4), Toqquz Sarai(A), Bezeklik Temple 9), the structure of square shrines is classified into five types: shrine surrounded by circumambulation passages and outer enclosure walls; shrine with a central altar surrounded by circumambulation passages and outer enclosure walls ${ }^{3}$; single-celled shrine with a

\footnotetext{
${ }^{2}$ The prefix 'pra' in Sanskrit pradakshina, as forming a part of this word, expresses proceeding round. 'Dakshina' means 'right', and signifies generally any matter respectable and convenient. Yijing writes, "Indians call the right hand 'dakshina', implying that to follow the right is respectable and convenient." He proceeds to mention that the ceremony of walking round towards the right three times is suitable to gain gift (I-Tsing, 1970:141). For such rituals, a Buddhist shrine or hall needs at least an assembly venue subsuming a cella with an altar and an ambulatory path, which were inevitable elements caused by the need for the rituals.

${ }^{3}$ The double-layered walls consist of the one enclosed walls behind the surrounding corridors and the other enclosed walls made behind the sanctum. Kurt Behrendt named
}

central altar; single-celled shrine; and four-columned shrine. The fifth type which appeared in Airtam II and Adzina Tepe Buddhist temples is based on the preexistence of Zoroastrian four-columned shrines in the pre-Buddhist period.

The thesis consistently examines the above-mentioned five types of Buddhist halls vis-à-vis "eight elements" applied in the architectural composition of the Buddhist temples in Central Asia, which rudiments were coined from early houses and public buildings of Near East, Central Asia, Northern India since the pre-Buddhist time, as well as stylistic features of Nabataean, Zoroastrian, and Gandharan temples in the pre-Buddhist period or the same. As a result, this study proposes the developments of Buddhist plans in consistent contacts with Buddhist tastes appeared in the synthesis of local idioms for constructions with architectural considerations universally required for ritual purposes.

This study further argues that the shrine plans in Buddhist architecture in Central Asia were closely related with Parthian(Iranian) and Nabataean(Syrian) temple, early house types at Near East and Central Asia, and fire temples, rather than GrecoRoman temple and megaron-type houses. ${ }^{4}$

them the shrines with double-layered walls "two-celled shrines": eg. "single-celled shrines" in case of shrines with single-layered walls (Kurt Behrendt, 2004). However, his definition does not deliver a clear meaning about the shape of the two-celled shrine because we can not convey what it is like if we do not see its image beforehand. Thus, in this thesis the type will be mainly defined as "a square shrine surrounded by circumambulation passage and outer enclosure walls," rather than the two-celled shrine, to avoid further confusion between forms and texts. But, in convenience sake, the term 'two-celled shrine' will be sometimes used in this thesis.

${ }^{4}$ The megaron appeared in a unit for domestic architecture in western Anatolia region of Early Bronze Age in the first Parthian period and at the same time the megaron appeared in Early Bronze Age (earlier) architecture of Thessaly and southeastern Europe of the Mycenaean culture, the megaron played an important role as a main public room like the throne of kings. The vernacular dwellings, whether rectangular or rounded, also contained a large hall and a storeroom behind it. They were elongated in response to demands for a larger, more formal structure; i.e. two posts in the interior placed longitudinally to support the ceiling. The megaron plan was remarkable at Tiryns (James Wright, 1982: 186-201). It has the walls of the vestibule pierced by three opening, clearly under Cretan influence, where such pillared walls are a characteristic feature (Valentin Muller, 1944: 347). 


\section{BUDDHIST MONASTERIES IN CENTRAL ASIA}

\section{1) COMPLEX AT AIRTAM AT UZBEKISTAN}

Airtam temple consists of two complexes. On the one hand, the lower building of the main temple (hereafter Airtam I) was built on the leveled ground of a natural hill dominating the banks (Galina Pugachenkova, 1991/1992: 27), and the Airtam I was circled by surrounding corridors, connecting with adjacent big and small rooms called a hilani. The cella belonged to four columns, and L-shaped and I-shaped corridors run behind the three walls of the hall. It is evident that the L-shaped and I-shaped passages, multi-layered narrow corridors, four columns inside the cella, and distyle in antis shared the important architectural features of fire temples. Such penchants strongly came from a local solution for the construction of Buddhist temples in the region. On the other hand, the complex of the higher Buddhist construction (hereafter Airtam II) was carried out on two levels. The upper level was located on the plain remains of the Greco-Bactrian building. On the bottom level from the north a rectangular court was surrounded by a clay wall. The temple had a pronaos (vestibule) and long entrance hall with surrounding passages and two additional rooms on the eastern side of the building (Pugachenkova, 1991/1992: 29). The entire plan is not typical of the Buddhist buildings of India and other locales located around the Mount Hindukush: it does not exist in the territory of Gandhara. Rather, the similar plans, except for an important monastery at Ak-Beshim, appear in the surrounding territory of Tian Shan, reaching Kucha, Shorchuk, Toqquz-Sarai, Bezeklik, and so forth, in rapport with fire temples that created the various types of surrounding corridors. Thus, it is concluded that this complex was produced by a local solution in that Airtam I complex employed the same four pillared halls, the composition of rooms on both sides, distyle in antis, and the L-shaped and I-shaped passages in the Buddhist temple as Zoroastrian temple did in the temples of Oxus, Susa, and Surkh Kotal at that time. (Fig. 2)

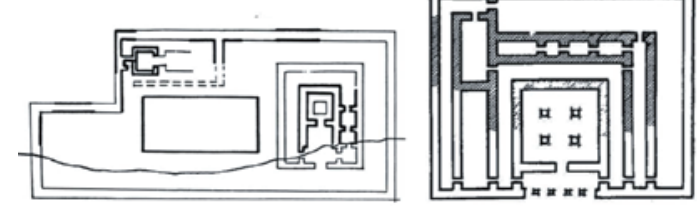

Figure 2. Airtam II (L) and Airtam I(R)

\section{2) AK-BESHIM AT TAJIKISTAN}

One of the important Buddhist monasteries, responding to the Buddhist monastery of Airtam, is in Ak-Beshim at the Chiu Valley. The monastery has a rectangular shape, 22 by 76 meters. The entrance, gateway, and vihara complex for monks were in the eastern part of the temple with an open courtyard along the walls. The courtyard proceeded to an open praying hall with four clay statues of Buddha sitting on high pedestals. The walls and the ceiling of the hall were decorated with painting. There was an eight-columned hall with a great flat ceiling between the sanctuary and courtyard, as presented in the eight-columned hall of Oxus temple, including three doors on three-flight of stairs in the western side: the central one leading to the sanctuary with a bronze statue of Buddha, and dome-like top, and decorated arch called iwan, which made a considerable contribution to making entrances and ornamentation of front facades in Iranian Islamic temples afterward; and the other two going to the side corridors round the rectangular cella, which was surrounded by three walls. In front of a cella, also, there were on two sides of a double-platform with sculptures of seated Buddhas on the floor.

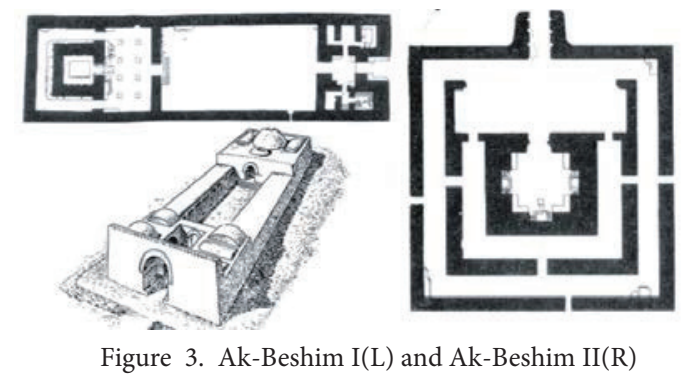

The plan has the same layout as megaron-type houses in Minor Asia and Zoroastrian temples in Gandhara and western Central Asia in terms of its proportion and composition (K.M. Paipakov, 1967). However, in that the eastern side occupied by cells is obviously different from them because the territory of vihara for monks was included, the original plan of the temple must be derived from the hilani front which is flanked by two rooms with towers. Further, Greek elements such as peristyle and distyle in antis are never shown in the temple (Fig. 3). Such tendencies for the subdivision of rooms and the composition of passages rather can be presented in building remains at Ay Khanum. (Fig. 28) The penchants for the subdivision of rooms and the composition of passages in the Ay Khanum Palace might be in the intimate links of building remains at Ak-Beshim temple, which adopted the L-shaped or I-shaped corridors and the subdivisions of the same passages and rooms as uncovered in Buddhist monasteries in Airtam I and II, Adzina Tepe, and Kara Tepe. In contrast, another temple at Ak-Beshim, dated to the seventh to early eighth centuries, had a quadrangle in plan, 38 by 38 meters. A cella with the size of 10.5 by 10 meters had a X-shaped plan by niches in the center of the western, southern, and eastern walls which include triple pedestal for deities. The central sculpture of Buddha was in the niche of the southern wall opposite the sanctuary entrance, and it was encircled by two corridors: i.e. the edifice consists in an open courtyard, a sanctuary and two side corridors joined with doorways in each side. The central entrance was in the northern wall franked by two strong pillars from the outside of the shrine. The outside of the shrine. (Fig. 3$)^{5}$ The second Ak-Beshim temple dated to the ninth to tenth centuries differed to a certain degree from Ak-Beshim. ${ }^{6}$ It consisted of a cella (3.2 by 3.2 meters) encircled by a corridor and a large hall entered from south-east. The corridor, 2.3 to 2.7 meters wide, encircled the sanctuary from three walls. There were two appendices-houses faced open to the yard (K. Paipakov, 1967).

\section{3) TOQQUZ SARAI AT XINJIANG}

Toqquz Sarai at Tumshuk consists of a large square court, a court with a large stupa. The large court and stupa court are aligned on a northwest-southeast axis, probably with the same arrangement as the main axis of Large Sanctuary. (Fig. 7) The large court has the

\footnotetext{
${ }^{5}$ The second Krasnorechensk temple likewise matched the first Ak-Beshim in plan. The sanctuary and small part of the yard in front of it, two encircling corridors, were placed along with a square cella in plan, 6 by 6 meters, with a dome-like top and decorated arch. The sanctuary was decorated with sculptural ensembles structurally connected with walls by wooden pillars (K. M. Paipakov, 1967). ${ }^{6}$ The temple matches the first Krasnorechensk (Kransnia Recha). (K. M. Paipakov, 1967).
} 
complete shape of square, measuring 10.8 by 10.10 meters, and a platform runs around the court. Large Sanctuary A, 50 by 32 meters, must be the oldest main temple complex, including some of the side rooms. Such tendency in Central Asia occurred in Tapa Sardar, and Dal'verzin tepe (Fig. 8, 9). ${ }^{7}$ The monastery also does not have orderly rooms. Large Sanctuary A has the irregular rooms, facing onto the stupa. It is very analogous to the courtyard plan with lopsided rooms of Complex B at Kara Tepe. (Fig. 6) At Large Sanctuary A, further, small temple I and J has a square base 1.9 meters, the platform for an image or a stupa, on each side with an ambulatory. Such long and narrow plans of the small temple I and J are shown in the elongated hall caves at Kizil, Kucha, and Shorchuk Ming-oi, which have the stupa or altar on a square base. They are different from those of Bamiyan and Hadda, which had stupas with square platforms and quadrangle cellas (four meters on each side) with a domed ceiling and four squinch arches. Indeed, such quadrangle plans had a less number than rectangular plans. In this sense, it is obvious that the dimension of cellas tended to get longer and bigger according to ritual demands over time.

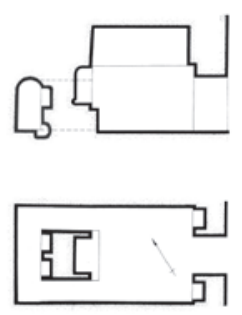

Figure 4. Cave 38, Kizil Grottoes

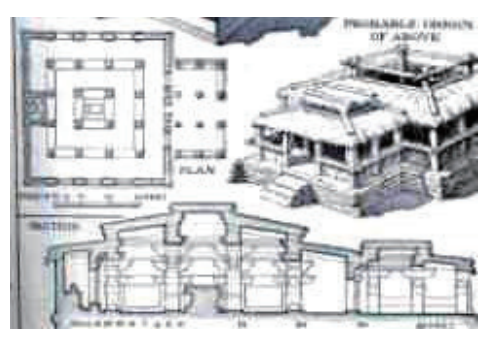

Figure 5. Ladh Khan temple
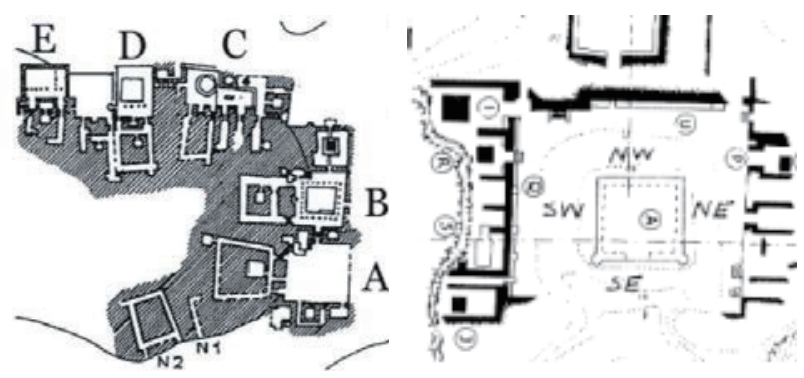

Figure 6. Kara Tepe

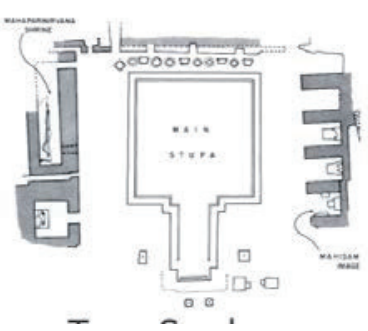

Figure 8. Tapa Sardar
Figure 7. Large Sanctuary A, Toqquz-Sarai

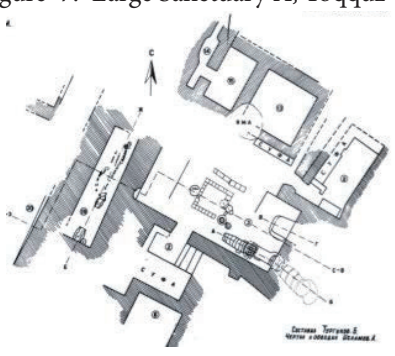

Figure 9. Dal'verzin-tepe

\section{4) CAVE 38 AT KIZIL (Fig. 4)}

Cave 38 at Kizil (the fourth century) has no antechamber or vestibule, and the main room reaches directly through the entrance

\footnotetext{
${ }^{7}$ Toqquz Sarai temple has the same composition as Gandharan temples that have a central stupa within a square court which is surrounded by smaller rooms and halls, modeled on Takht-i-Bahi, Thareli, Jamal-Garhi, Sahri-Bahol, and MekhaSandha at Peshawar, Nimogram, Saidu Sharif I, and Butkara I at Swat, Jaulian, and Dharmarajika at Taxila, as well as some monasteries surrounded by smaller rooms to hold statues or votive stupas at Hadda, Begram, and Fondukistan.
}

along a central axis. Notable is that early Buddhist monasteries such as Kara-tepe, Toqquz Sarai A, and Karadong built around the fourth century did not have any antechamber. Yet, in the time of course, long and narrow plans with an antechamber and a porch became widespread in Xinjiang region. On both sides of the back wall of the main room is an arched passageway leading to the rear chamber which is very narrow like a corridor. These passages create a square unit, called the central pillar (Ho Puay-peng,1992:61). However, it does not seem that it does have a pillared stupa because only arched niche or walls can be seen in the front of our eyes. Such monasteries with a central pillar are a process to confirm the relationship between the divine and the human by circumambulating the shrine (M. Maillard,1983:133). The long and narrow hall popular in the territory of the Silk Road, as above-noted so far, may have close relationships with ceremonial performances for the faithful: narrow surrounding corridors for the pradakshina cult, anterooms for the preparation of rituals, and elongated plan for communal rituals. Such symmetrical elongated plans become a common language because most of buildings such as early houses in Near East and Anatolia, Nabataean and Greco-Roman temples, Indian cave temples and open-air temples with square plans, Kizil, Dunhuang, etc. adopted elongated plans due to the demands of division rituals between cooperate and individual rituals, and the augmentation of ritual performance (I-Tsing, 1970: 121; Lars Fogelin, 2003, 2006; H. Sarkar, 1966).

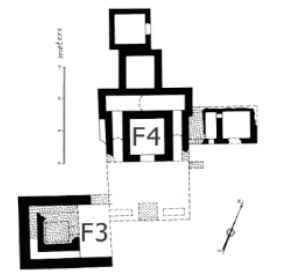

Figure 10. Shorchuk Ming-oi

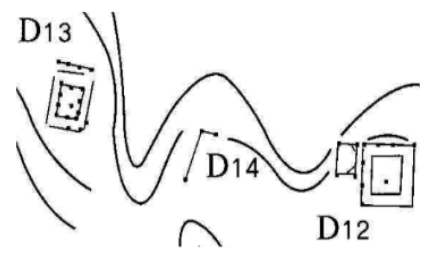

Figure 11. Dandan Oilik n. 12, 13
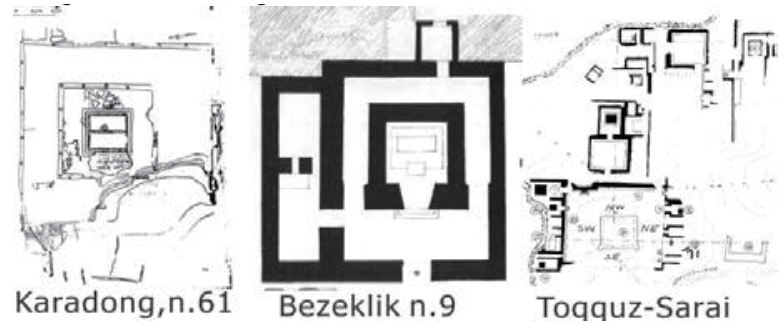

Figure 12. Karadong (n.61), Bezeklik(n.9), Toqquz-Sarai

\section{5) KARA TEPE, DANDAN OILIK, KARADONG, AND SHORCHUK MING-OI AT XINJIANG}

Unlike central pillar types with a elongated hall, another transformed pattern with a sanctum with an altar platform and surrounding corridors began in Dandan Oilik, Karadong, Bezeklik, Kucha, Shorchuk Ming-oi, and Toqquz-Sarrai (Tumshuk). The above-mentioned elongated halls were intended for corporate rituals, whereas the quadrangle sanctum was planned for individual rituals because enclosed walls were established along the altar inside the shrine. Dandan Oilik D12(Fig.11,14) has a squarebased sanctum with a surrounding corridor and a pradakshina patha, and includes an interior wall length of three meters, which is surrounded by another rectangular wall, 4.4 by 4.8 meters. The narrow path between the enclosed wall and the cella served for the pradakshina (Christoph Baumer, 1998: 10). 


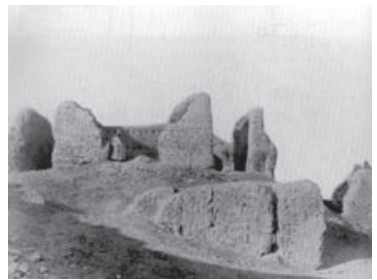

Figure 13. Shorchuk Ming-oi, F4

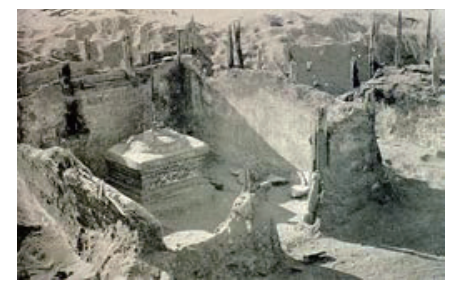

Figure 14. Dandan Oilik, D12
In like manner, Karadong n.61 monastery near Keriya (near Khotan) on the Southern Route, which dates to around the second half of the fourth century, consists of a quadrangular cella (each 8.5 meters) with a central square altar or stupa, but without an antechamber. The cella is surrounded by a circumambulatory passage and a rectangular outer enclosure wall, measuring two meters on each side containing the wall paintings (Fig. 12). The cella type also appears at Kara Tepe on the south side of the main court of Complex A, which does not have an antechamber. The type indeed occurs in F4 shrine at Shorchuk Ming-oi. A mound in the cella was in the center which might be placed in a stupa or statue (Aurel Stein, 1921: 1190) (Fig.10, 13). The F4 had a great staircase on a large podium to enter inside the shrine.

On the contrary, the basic type of the Buddhist temple with surrounding corridors was represented in one of the over-ground sections of the Buddhists monastery of Kara Tepe in Termez. ${ }^{8}$ These surrounding corridors were variously and repeatedly revealed in this area and L-shaped and I-shaped corridors run behind square shrines, where the cave sections repeated the same layout. Notable is that the distance between each of shrine and surrounding corridor was much deeper than other monasteries. Even later, this layout was frequently used in other monasteries such as Guldara(Guru dara), Adzina Tepe at around Gandhara as well as neighboring regions: Kucha, Sengym(Senguim-Oriz), Karashar(Shorchuk Ming-oi), Subashi, from the sixth to seventh centuries C.E. (Fig. 15, 16)

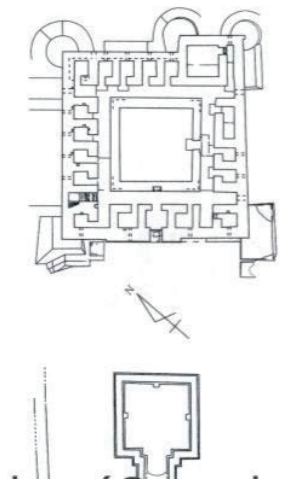

Figure 15. Guldara(Guru dara)

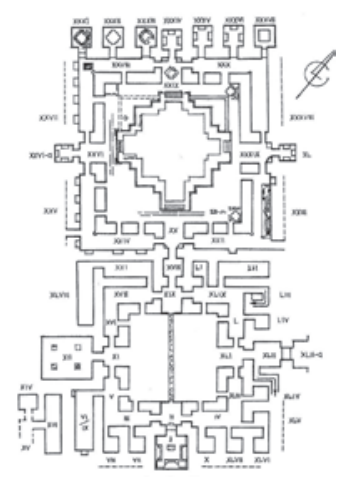

Figure 16. Adzina Tepe

\section{6) FAYAZ TEPA IN TERMEZ OF UZBEKISTAN}

Dating from the $1^{\text {st }}$ century B.C.E., Fayaz Tepa Buddhist monastery, in the northwestern part of Termez, comprises a stupa facing a main shrine and a rectangular monastery (117x34meters) divided into three parts along a north-south axis, with the kitchen/ refectory to the south. There is an open-air courtyard and an arch gate like iwan flanked by small rooms like the hilani front between the main shrine and main stupa, in which the monastic quadrangles were situated on the both sides, holding a symmetric arrangement

${ }^{8}$ There are significant Buddhist temples in three locales near Termez: i.e. Fayaz Tepa, Kara Tepe, and Adzina Tepe.

(Kato Kyuzo,1992:35-38). The middle courtyard is also surrounded by small rooms and I-shaped roofed and colonnaded passages. Its arrangement follows the similar way in that the Ak-Beshim I subsumes an open-air courtyard between an entrance and a shrine. (Fig. 17)

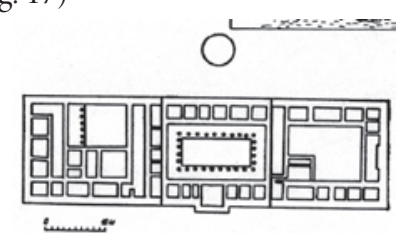

Figure 17. Fayaz Tepa

\section{ARCHITECTURE IN PRE-BUDDHIST PERIOD}

\subsection{VEDIC ALTAR}

It is believed that the establishment of a square-based platform in Buddhist architecture has been based on Vedic square altar. Indian architects used a number of ideas to build religious architecture. Such ideas can be classified into three parts; the Indian architecture has commonly used a square plan persistently related to the construction of Vedic altars (Stella Kramrisch, 1946:15); a gridwork to weave space and time'; and symbolic ornamentations to get an attractive sight for believers. Likewise, through a long historical context of the Vedic altar, the laying out of the Hindu temple has been a ritual, and most prototypical stone temple is characterized by a square plan with cardinal projections (Michael Meister, 1979: 204-219) ${ }^{10}$ and a curved superstructure with vertical band (latas) over the wall's projections. The square plan means the Nabel (nābhi) in the Vedic rites, as the womb, in the center of the UttaraVedi. On the altar the fire was laid on the Ukhā, the fire-pan made of clay. The Fire (Agni) is carried in the pan from the Âhavaniya hearth (Stella Kramrisch, 1946: 26-27) ${ }^{11}$ However, Kuwayama Shoshin believed that the square platforms started to appear in Indian stupas right when the wheel-shaped stupas began to appear under the influence of Roman mausoleum architecture in the time of commercial contact between Roman and Indian regions (Kuwayama Shoshin, 1978:209-210). Kuwayama also questioned his arguments because he could not find any historical records that Roman architects visited in Indian regions to construct temples (Kuwayama,1998:506-566). An interesting point is that the altar includes a solid platform with a series of engaged columns inside, providing the impression of a peristyle.

\subsection{NABATEAN MONUMENTS IN NEAR EAST}

In Ak-Beshim I Buddhist temple (Fig.3) and Mohra Maliaran at

\footnotetext{
${ }^{9}$ Vedic rites introduce and accompany the building of the temple. At the beginning of the various phases in the construction and consecration of the temple, the rite of the seeds and their germination (ankurärpana) is most important. The ploughing and sowing of the sacrificial ground with all kinds of grain preceded the piling of the fire altar, the building of the temple (Vaikhānasāgama). In the Upanisads, the world is woven by Brahman.

${ }^{10}$ The Brhat Samhita prescribes rules regarding orientation toward intermediate directions are waived since the temple should always be oriented toward the cardinal points.

${ }^{11}$ According to the stipulation of the Baudhayana Sulba sutra, the first makes a square (caturaśrikarana) delineating the outer periphery of the temple, its division in half, fixing of poles in the middle of the east-west line at the cardinal points.
} 
Gandhara (Fig.36), notable is that the porch-like front is flanked by two rooms or towers, which might be coined from a hilani front in Nabataean temples. Puchstein was the first scholar to deal with and define the term hilani. He concluded the term came from the Assyrian sources of the eighth and ninth centuries B.C.E., Also, from the Annals of the Assyrian kings who mention in their building-inscriptions, Puchstein interprets the word as referring to a portico flanked by two rooms (Puchstein, 1892). Koldewey had the agreement with his opinion; yet, he writes, "lying behind the main area toward the direction of the entrance"12 (R. Koldewey, 1898). The definition was a little different from Puchstein. But, they had a common point in that they amalgamated the hilani to a certain type of building as a technical term. By contrast, Weidhass talked about the definition in a philological consideration, he writes, "There continually existed nothing as from a set of columns. By the way it could be... the opening of walls should be only one by only a column"13 (Hermann Weidhaas, 1939). Thus, because most definitions were not scientifically proved, Wachtsmuth, through archeological finds at Sendsjirli, concluded that the oldest examples of the hilani type must be accepted as a prototype. Thus, he said, "as long as it remained refused scientifically, the older models, i.e. this building type from Sendsjirli must be called a prototype of the

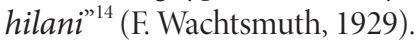
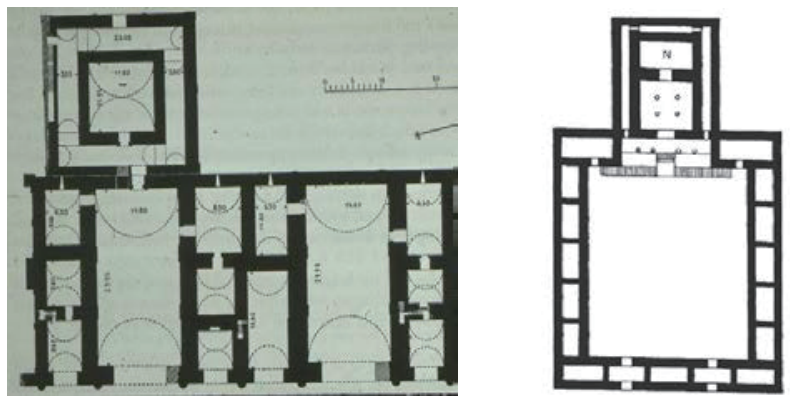

Figure 18. Palace at Hatra (L) and temple (R) Figure 19. Kuh-i-Khawaja, Iran

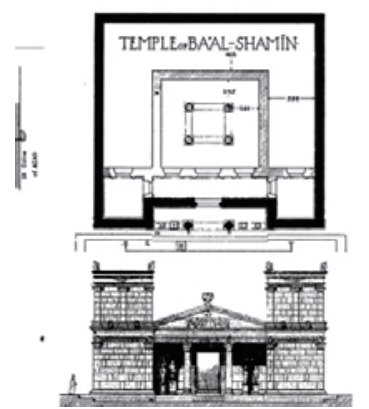

Figure 20. Ba'al Shamin, Syria

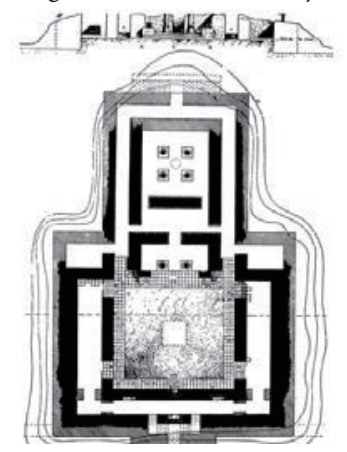

Figure 21. Fire Temple at Susa
We may find it in a type of the temple Herzfeld excavated in Kuhi-Khawaja(Fig.19), which is a square room surrounded on all four sides by a roofed corridors. Herzfeld had discovered about a dozen in Iran in the ten years following his excavation works of Kuh-i-

\footnotetext{
${ }^{12}$ Die Querlage des möglichst offenen Vorraums und dieselbe Lage des dahinterliegenden Hauptraumes zur Eingangsrichtung.

${ }^{13}$ Er bestand aus nichts weiter, als aus einer Reihe von Säulen. Es konnte übrigens auch.. nur eine durch eine einzige Säule gehälftete Maueroeffnung sein.

${ }^{14}$ Solange es der Wissenschaft versagt bleibt, ältere Vorbilder dem Sendschirlier Bit-Chilani entgegenzuhalten, muss dieser Gebäudetypus aus Sendschirli als Urform bezeichnet werden.
}

Khawaja(Ernst E. Herzfeld, 1935). Precisely the same arrangement was used in an addition to the principal palace at Hatra, adding a temple with a central sanctuary and a roofed passage on all four sides (Fig.18). This temple plan was used in Iran of the Parthian time but even earlier under the Achamenids. ${ }^{15}$ There exists on the Zoroastrian temple of Susa(Fig. 20), attributed to the fourth century B.C.E. the same feature likewise revealed in the temples of Nabataean Syria. The temples of Baal Shamin(Fig. 20) and Dushara at $\mathrm{Si}$, and the sanctuary at $\mathrm{Sahr}$ (all built in about the first century C.E.) show a remarkable similarity to the plan of the Susa temple.

\subsection{ZOROASTRIAN PILLARED HALLS AND PASSAGES (I / L)}

Indeed, the role of Zoroastrian temple as a mediator of Buddhist ideas was significant because they had been in the same period and the same territory side by side with early Buddhist buildings in favor of the aniconism against the creation of images. The general identification of fire temples was that the most characteristic trait was the core of the temple: a four-columned hall with an altar surrounded by peripheral corridors as shown in Buddhist temple complex at Airtam I and a hall for monks at Adzina Tepe.(Fig.23)

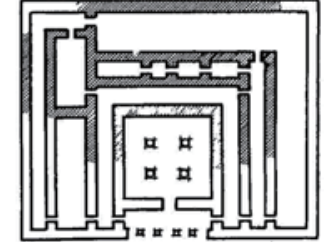

Figure 22. Pillared Hall/Passages Airtam I

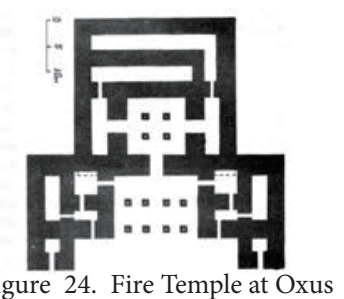

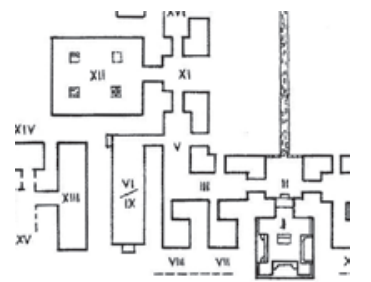

Figure 23. Pillared Hall at Adzina Tepe

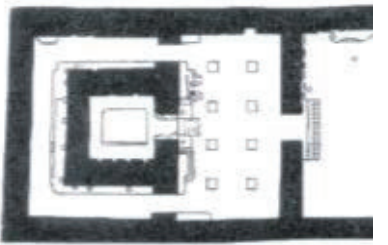

Figure 25. pillared hall at Ak-Beshim I
In Adzina Tepe, most shrines consisted of figured walls and pedestals, and there was a votive stupa in the center. The rooms which were of different sizes were led through iwans which had their different modes of arrangements and functions. The iwan led into a room (10.25X9.5m; room XII) with its roof supported by four columns (Fig.16). But, unlike the four-columned hall of fire temples, the room was concluded as the meeting place (posathagara) for the monastic community, although it has been as yet not sure (Litvinski1., Boris Anatol'evich, 1971: 221). Another four-columned hall in Buddhist architecture existed in Airtam I (Fig.2). The main hall has the same shape as the cultic rooms of fire temples in the neighboring areas. Then, the construction of Airtam I was completed in the introduction of a regional plan, but the plan had a broad distinction in two points: the plan applied surrounding corridors for the circumambulation behind the main hall; and the temple also did not show the perfect facade of the hilani. The rooms might be remodeled in the combination of other small

\footnotetext{
${ }^{15}$ Stronach argued "their ground plans recall those of the Greco-Bactrian residence" because the Bactrian reception unit and court/portico unit at the expense of the inverted ' $U$ ' of the living quarters (D. Stronach, 1985:618).
} 
rooms in the consistent uses of the building. The combination of four columned halls and distyle in antis has been only shown in the megaron-typed buildings and Bảal Shamin in Syria so far (Fig.31), and has not yet found the same residential constructions with the pillared halls as those excavated in Central Asia, India, and Near East. Nonetheless, it will be observed that neither the plan nor the elevation of the fire temples have anything in common with a Greek temple except the columns of the Ionic order and the cella divided into a naos and pronaos, although it appear that in northwest India a few buildings have Greek features. In addition, the small chambers on either side of the square four-columned hall are where the eternal fire was kept, one of the compulsory, and important components of the interior functional structure of temples. AkBeshim I is a representative case about the use of the pillared hall as an anteroom. In that the eight-columned hall between the sanctuary and the courtyard employed a great flat ceiling and a vestibule with columns two rows deep, the construction method obviously rests on Parthian (Achaemenid), which also occurred in the fire temple at Oxus. It shows that the construction of temples depend on local methods of building.

\subsection{DWELLINGS IN PRE-BUDDHIST TIME 1) EARLY HOUSES IN NEAR EAST}

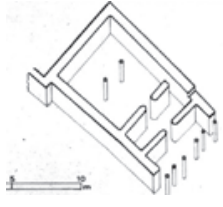

Figure 26. Ain Ghazal

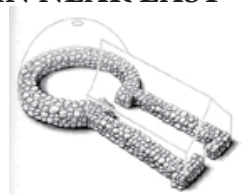

Figure 27. Arpachiyah

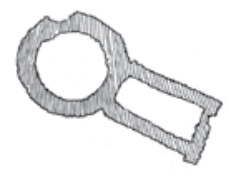

Figure 28. Halafian
Closely packed rectangular houses at Arpachiyah in Syria(Fig. 27) were built with their round structures similar to the Halafians (the 65th century B.C.E) (Fig.28) well-known for their round homes. They all have rectangular annexes attached in a keyhole pattern that resembles the later tholoi of the Aegean. Houses of Ain Ghazal (the 72nd-55th century B.C.E.) (Fig.26) in Jordan with closeness of the dwellings like Arpachiyah were built with rectangular mudbrick houses that accommodated a square main room and a smaller anteroom and corridor with the entrance at top center (Mary Settegast, 1986). A symmetrical plan was another feature, albeit they had different shapes of plan: the square plan and keyhole-shaped. The symmetrical layout of the type would demand the use of the place through the procedure of a partition at the front wall, as the later Nabataean temple actually does.

\section{2) EARLY HOUSES IN CENTRAL ASIA}

The palaces and homes in Dalverzin-tepe and Dilberjin were laid out either with a central hall and vestibule or with a courtyard - the whole being surrounded by a corridor. Houses in Dilberjin employ a central hall and a colonnaded portico with a corridor flanked by the rectangular mass of the sanctuary (Paul Bernard and UNESCO, 1994:331-337). The house also has a courtyard in front of the body of the building firmly centered around the main living-room. A peripheral corridor set off the living-room from the other. This living room opened out into the front courtyard through a twocolumned porch in case of the houses of Dalverzin-tepe.(Fig.29) Also, Ay Khanum was constructed as one of the consequences of the conquest of the East by King Alexander in the fourth century B.C.E. But, the buildings such as temples, houses, and palaces are never characteristic of Greek architecture. Paul Bernard mentioned the reason in the following manner "as the Greek architects did not have their own prototype to imitate for the design of the palace at Ay Khanum, they drew their inspiration largely from the NeoBabylonian and Achaemenid models (so-called Nabataean style) they had seen when they first entered the region with the Greek armies"(Paul Bernard, 1994:106-110), albeit it was characteristic of Greek town planning. Thus, like the Achaemenid palace of Susa, the palace at Ay Khanum consists of a massive conglomeration of courtyards. The main courtyard, through which the palace was entered from the north, has its imposing size (137 x 108 meters) by the rows of stone columns, crowned with Corinthian capitals, which formed the façades of its four porticos. Behind the southern portico, a vestibule with eighteen Corinthian columns three rows deep. Paul argued "it is reminiscent of the spirit of some Achaemenid architectural compositions," (Paul Bernard, 1994:107) as a monumental entrance. Passing the imposing entrance, another courtyard for official uses is a huge square, 50 meters each side, divided by two I-shaped corridors at right angles into two pairs of similar units, including one room on each side. The composition rests on the same method as the hilani front originated from Nabataean architecture. (Fig.30)
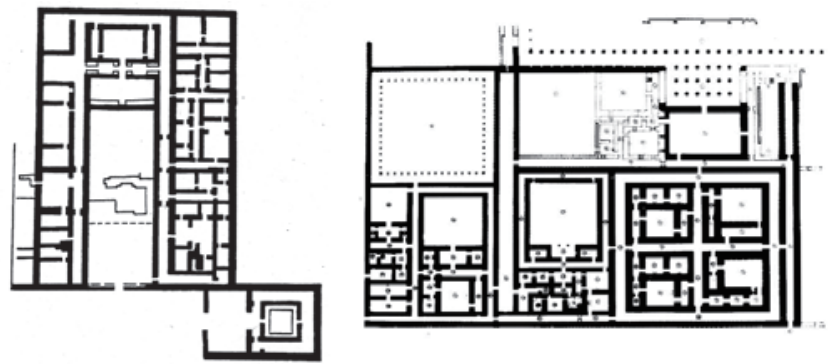

Figure 29. Dilberjin(L), Figure 30. Ay-Khanum(R)

\section{3) MEGARON TYPE IN ANATOLIA}

Schliemann pointed out the term "megaron" has subsequently been not only augmented to include other buildings containing a long hall and a porch in front, but free-standing buildings with this alignment of rooms; apsidal buildings have also been subsumed. ${ }^{16}$ In the same manner, Müller indicated the general type of megaron is the long room, i.e. a room with four walls having two different lengths and thus differing from the square room which has all four walls of the same length; the decisive characteristics of the long room is the position of the entrance, which is in one of the shorter walls, thus the depth of the room is longer than its width (Valentin Müller, 1944: 342).

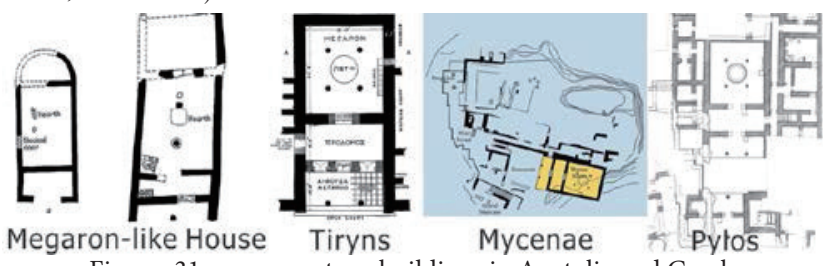

Figure 31. megaron-type buildings in Anatolia and Greek

The original type is an isolated rectangle, and a number of additions were made to the simple original type during the course of the development, i.e. a porch or an anteroom, interior posts and a partition. The occurrence of the partition in the houses proves

${ }^{16}$ Schliemann borrowed the term "megaron" from Homer to explain the palaces, or the central unit of the palaces, of the late Mycenaean period on the Greek mainland. 
that the co-existing agglomeration type was not unnecessary. In the following period, houses with a porch or an anteroom and a subdivision were constructed in the appearance of the partitions in the houses. A few apsidal types of the house appeared at Eutresis, Korakou, and Thermos, which had the back wall curved. The front is either an open or a closed anteroom, and the long central room was flanked by the smaller rooms at the ends. The well-balanced plan originated from a fusion of the long type with curvilinear walls was widespread in Greece at that time (Hetty Goldman, 1931:3537; Müller, 1944:345; Mattias Valmin,1939:148). (Fig.31)

\section{SOLUARE PLANS IN NABATEAN, ZOROASTRIAN, AND GANDHARAN REGIONS}

\subsection{NABATEAN TEMPLES IN THE SAME TIME 1) BA'AL SHAMIN, SYRIA (Fig.20)}

Baal Shamin temple, built in the first century C.E., holds the features of temples Nabataean Syria because it has a square room surrounded on all four sides by a roofed corridor and the hilani front as well as distyle in antis, which was generally engaged in the front entrance of early rectangular houses of Near East and Central Asia. In particular, it has a four-columned shrine in the same manner as the central shrines of Zoroastrian temples.

\section{2) KASR- IL-ABD (Fig.32)}

The Kasr- Il-Abd, built in the second century B.C.E., is a solid walled structure with a series of engaged columns inside, thus giving the impression of a peristyle to one within the temple. A synthesis of a peristyle and a surrounding wall in Parthian period belong to a temple of Roman provincial type. What is important is a row of columns which surround the building only along the front of the temple like a peripteros. But, the way which these columns are connected by arches supported by the edges of the Ionic bases of the columns was used in the Parthian palace at Assur in the first century C.E. which had four iwan halls facing four cardinal directions of a huge courtyard, subsuming a pillared hall and another colonnaded courtyard behind the open court. (W. Andrae and H. Lenzen, 1933).

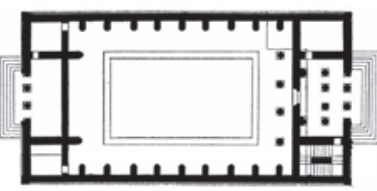

Figure 32. Kasr Il-Abd

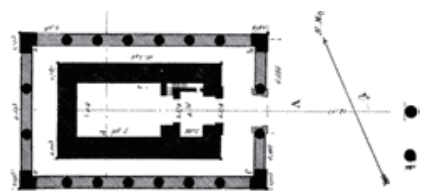

Figure 33. Temple at Edfu
3) TEMPLE AT EDFU, EGYPT (Fig.33)

In Egypt during this time under the Ptolemies and then later under the Romans a type of temple was built which corresponds to those used in Syria. Both the Edfu Temple and Dendhera Temple have a peristyle surrounding the sanctuary, but the pillars are linked by a wall in the lower part, thus enclosing the cella rather than holding the openness of a peristyle (Earl Baldwin Smith, 1938). This existence of these structures in Egypt and Syria is so similar to the temple at Jandial under discussion in northwest India because of the application of inner columns along the peripheral corridors.

\subsection{ZOROASTRIAN TEMPLES IN THE SAME TERRITORY 1) JANDIAL TEMPLE AT GANDHARA}

Jandial temple at Taxila, which was considered to be the fire temple, but still debating on the use, whose plan is distyle in antis, which was also shown in the plans of Greco-Roman temples (including the later megaron), Zoroastrian temples (Sir John Hubert Marshall, 1921:35-39). The building faces south and has at its main entrance two Ionic columns between the front parts of an enclosing wall, thus forming a so-called hilani façade (Fig.35). There is another pair of Ionic columns in antis beyond the vestibule. Through them the faithful reach the pronaos and then through a doorway they reach the naos. At the back of the temple a small chamber is linked with a staircase. This rear chamber corresponds to the Greek opisthodomos. However, the building is surrounded by a wall which is pierced at regular intervals by windows. The method does not suggest the peristyle of Greek Temple because the walled peristyle was accepted in the Parthian palaces and temples (e.g. the temples of Bảal Shamīn and Dūsharā at Sî, Kasr Il-Abd, Temple at Edfu, and Temple at Dendhera) in Nabataean Syria and Egypt, which have a solid walled structure with a series of engaged columns inside. Particularly, Edfu temple shares many common points with Jandial temple in that the columns are connected by a wall in the lower part, and the cella and anteroom are enclosed by solid walls.

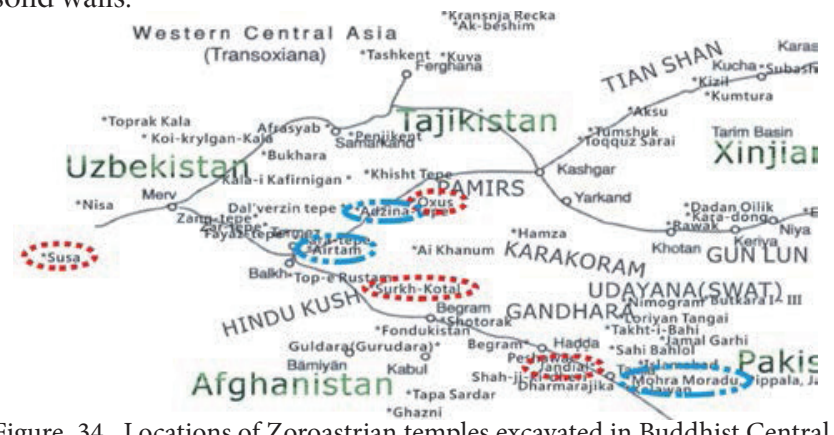

Figure 34. Locations of Zoroastrian temples excavated in Buddhist Central Asia and Gandhara regions (red circle)

The blue circles indicate the location of Adzina Tepe and Airtam I(upper), and Mohra Maliaran (bottom), respectively.

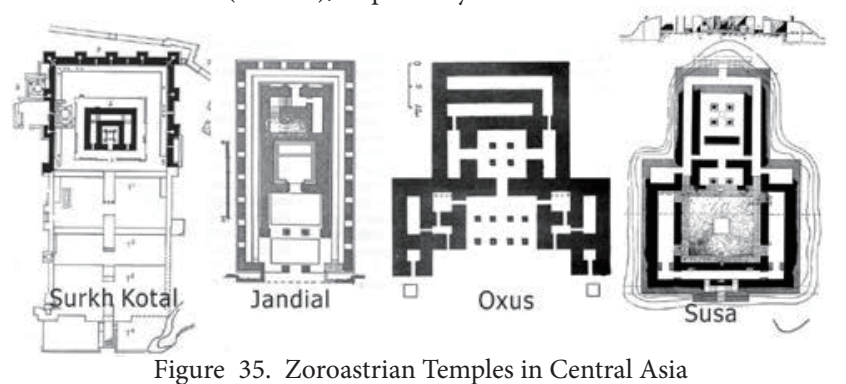

2) SUSA TEMPLE AT UZBEKISTAN (Fig.21,35)

The Susa temple consisted of a courtyard and square, raised sanctuary with an antechamber. Within the sanctuary were four free-standing pillars, which must have surrounded the cult object. K. Erdmann writes, "The arrangement is clear. The square place is actually ateshgah, therein was the holy fire burned. The lateral areas might have contained wood and other materials necessary for the cult. To the public ceremonies, the flame was brought into the prostas (antechamber or vestibule)"17 (K. Erdmann,1941:15-16). The same feature has been found in the temples of Nabataean Syria: the temples of Baal Shamin (Fig.20) and the sanctuary at Sahr of the

\footnotetext{
${ }^{17}$ Die Anordnung ist klar. Der quadratische Raum ist das eigentliche ateshgah, in dem.. das heilige Feuer brannte. Die seitliche Räume dürften Holz und anderes für den Kult erforderliches Material enthalten haben. $\mathrm{Zu}$ den öffentlichen Zeremonien wurde die Flamme in die Prostas gebracht.
} 
first century C.E. The two examples present a remarkable similarity to the plan of the Susa temple. Indeed, de Villard said in the observation of the Jandial temple, "it is not difficult to find the plans of building in Iranian idea, through which the cella was isolated by a covered corridor that separate it definitely from the outer world" (Ugo Monneret de Villard, 1938). Thus, as Osaca Reuther said "ultimately of Iranian origin" (Oscar Reuther, 1939), the Susa temple also accepted Iranian idea because the idea of isolating the cella by a surrounding corridor was applied to the same manner. There are two possible depictions for the façade of this type in two different locales; both are derived from Syria, or the origin of the Nabataean temples was from Persia. Indeed, Oelmann also talked about the possibility that both the Nabataean and Persian architecture had their common origin like the hilani front in the ancient building of Syria and Egypt respectively (Franz Oelmann, 1921: 273-88).

\section{3) OXUS TEMPLE AT TAJIKISTAN (Fig.24,35)}

Temple of Oxus at Bactria, unlike other Buddhist monasteries, had the central four-columned hall in its core, with extant walls close to twelve meters in height and three monumental doorways: three meters in width and depth (B. A. Litvinskii,1994:13-25). The main entrance on the east side leads into the eight-columned iwan; the direction of the gate has similar orientation of the typical Indian and Greco-Roman temples. The southern doorway leads into the first corridor. This in turn connects through the second doorway, which is perpendicular to the first corridor, running behind the west wall of the central hall. Taken together, the corridor-like two L-shaped rooms are the same as those of a temple at Airtam and the cave hall of Complex C at Kara Tepe.(Fig.2,6) The hall and its peripheral corridors keep a square ( 32 by 32 meters). On the east side this is abutted by a long, centered rectangle ( 51 by 17 meters) divided into three units of almost identical size of 17 by 17 meters. In the middle is the eight-columned iwan, ${ }^{18}$ flanked by a north and south wing symmetrically. The eight-columned hall appeared in the Ak-Beshim I Buddhist temple as an anteroom.(Fig.24,25) This temple was influence by three traditions of Achaemenid, Greek, and Nabataean tradition. Firstly, the structure of iwan and separated surrounding passages follows the traditional Achaemenid standard (U. Scerrato, 1977:713-30; Roman Ghirshman,1962:32). The order and materials of the columns (Ionic order) and monumental altars demonstrate that there was Greek influence. Likewise, the porchlike façade is flanked by two rooms, and it is called the hilani front which was influenced by Nabataean Syrian architecture.

\section{4) SURKH KOTAL TEMPLE AT GANDHARA (Fig. 35)}

Surkh Kotal temple consists of two parts. At the top of the hill the ground-plan of a sanctuary and square cella with four internal pillars and surrounding corridors observe the usual principles of Zoroastrian temples; i.e. it succeeds to the architectural traditions of fire temples derived from Persian and Nabataean culture: at Susa, Oxus, and Persepolis. On the contrary, on the east side of the hill the great platforms for access were divided into four terraces, reaching the innermost sacred area at the top by the colossal flights of steps. Surkh Kotal also gives an interesting similarity, which can be applied to other fire temples, with Buddhist sanctums with surrounding corridors such as F4 temple at Shorchuk Ming-oi,

\footnotetext{
${ }^{18}$ Parthian architecture always maintained links with the nomadic habit. It would seem that the iwan derived from the tent, one side of which contained an opening, in the central courtyard of the Square House with its four iwans.
}

Airtam, and Ak-Beshim. (F.R. Allchin and N. Hammond, 1978: chapter 5).

\subsection{GANDHARAN BUDDHIST TEMPLES IN THE SAME TIME}

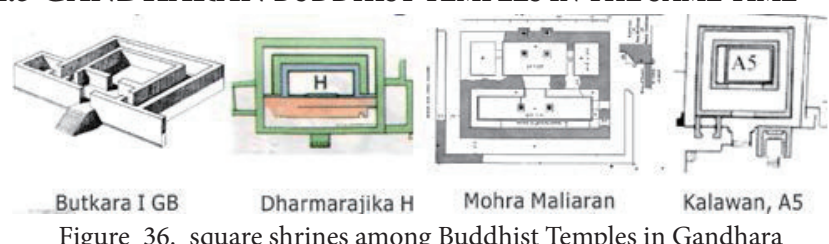

The square shrines of Gandharan monasteries were characteristic of those surrounded by circumambulation passages and outer enclosure walls: e.g. Butkara I (GB) at Swat, and Dharmarajika (H) at Taxila. The GB shrine at Butkara I was placed on a raised plinth, more than two meters, on which the traces of chisel marks along the facade base of the building (GB). They indicate that sculpture was arranged there, along the side of stairs on the front. The GB also consists of a main cella and an anteroom. The cella has enclosed walls with a surrounding corridor behind the walls of cella: the GB is the only massive example of a two-celled shrine (Daniel Schlumberger, 1952: 240-4, 433-53). The shrine also is flanked by one room on each side of the front-like porch. This is the same structure to the shrines of Dharmarajika $(\mathrm{H})$ and Kalawan (A5). In particular, the $\mathrm{H}$ shrine of Dharmarajika is flanked by two rooms on both sides (Fig.36). Though this had been among the earliest remains of Indian area, such manner was shown in a sanctuary of Bactrian Ay Khanum, founded in the earlier date than Gandharan monasteries. Accordingly, it is evident that such type is originated from Nabataean Syria as mentioned previously, rather than Anatolian origin. The type of shrine surrounded by circumambulation passages and outer enclosure walls has appeared in most of Hindu Temples for similar purposes of image enshrinements and circumambulatory practices as seen in Ladh Khan (the fifth century), Durga temple (the sixth century) at Aihole, Kailasanatha Temple (the seventh century) and Vaikunta Perumal (the eighth century) at Kanchipuram, and Virupaksha at Pattadakal (the eighth century). (Fig.5)

\section{THE CHARACTERISTICS OF FIVE TYPES IN CENTRAL ASIA (SEE TABLE 1 AND 2)}

The table 2 illustrates how the Buddhist temples in Central Asia were represented responding to building elements dwelling upon early houses, palaces, and religious temples which were constructed in Gandhara, Central Asia, Near East, and Anatolia. The main shrines of Buddhist temples in Central Asia can be classified into five kinds: a square shrine surrounded by circumambulation passages and outer enclosure walls; shrine with a central altar surrounded by circumambulation passages and outer enclosure walls; single-celled shrine with a central altar; single-celled shrine without any altar; lastly, four-columned shrine. Also, the square shrines of these temples depending on five major types were built resting on eight elements for the composition of these temples, which were significant for functional purposes. The ingredients are composed of the anterooms(i), distyle in antis (columned entrances)(ii), the hilani front(iii), I/L-shaped corridors(iv), elongated hall(v), iwan hall(vi), colonnaded passages(vii), enclosed courtyards(vii) between the main shrine and entrance, which came 
from local residential, imperial, and religious architecture.

Table 1. Square Shrines of Buddhist Temples in Central Asia and the relationship between pre-Buddhist architecture and contemporary architecture in the same area.

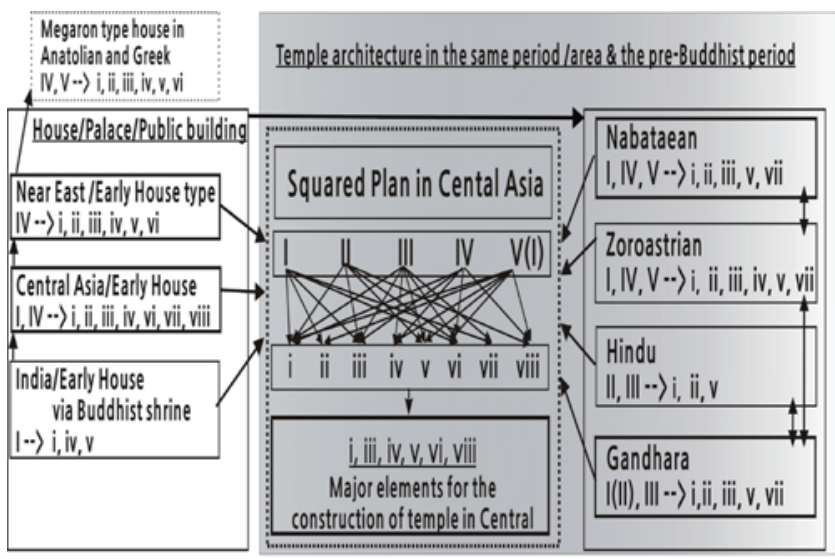

Based on Table 2, likewise, through the qualitative analysis between all of Central Asian Buddhist temples with perfect line drawings and other religious, residential, public architecture founded in the same period and locales which are dealt with in this study, the major elements for the construction of Buddhist main shrines in Central Asia are unveiled as five ingredients. In other words, they are mainly composed of six components: anteroom(i), hilani(iii), I/L-shaped passages(iv), elongated hall(v), iwan(vi), and courtyard(viii). Also, Central Asian Buddhist temples were in close rapports with early houses and temples of Central Asia (Bactrian) and Near East (Nabataean and Achaemenid), rather than Anatolian and Greek monuments.(Table 1)

The type I appeared in Kara Tepe, Airtam I, Ak-Beshim II, Dadan Oilik(D12), Shorchuk(F4). Such type has already taken place in the palatial and religious buildings at Hatra (the first century C.E.) and Ay Khanum, in addition to houses of Central Asia (the fourth century B.C.E.). The building type was also applied to enclosed shrines embedded on each wall with the sculpture or painting, or sculpture in the center without a plinth. The square shrine type I appeared in the early houses of Central Asia and the Zoroastrian temples of pre-Buddhist period, and frequently in intimate connections of the type II and V.

Also, the type II belongs to Airtam II, Ak-Beshim I, Karadong n.61 constructed around the fourth century C.E., and Dandan Oilik D12 built after the sixth century C.E. The type (II) was considered as Indian origin because Hindu temples had used the type since the early Buddhist period. The Ak-Beshim I, as above-mentioned, accommodated the local method of architectural composition in Bactrian Central Asia: i.e. hilani, enclosed courtyard, elongated plan, distyle in antis (eight pillared hall), and iwan, all of which came from local methods popular in the territory in pre-Buddhist and Buddhist period. Either the two-celled (I and II) or singlecelled shrine (III and IV) with "entire enclosure" was an important plan useful to the faithful who want to gain solemn environments for ritual performances whether the loci were used for the pradakshina path or religious assembly.

The type III subsumes Kara Tepe (I+III), Dal'verzin-tepe, and such cave monasteries as Kizil, Toqquz Sarai, etc. at Xinjiang, which are characteristic of elongated shrine(v), I/L-shaped corridors(iv), and enclosed courtyard(viii). The type further can read a process of development about the anteroom(i) because monasteries built around the fourth century such as Kizil n.38, Toqquz Sarai, and Kara Tepe do not have it. On the contrary, the type IV manages Fayaz Tapa, Gul dara(Guru dara), Tapa Sardar, and Airtam II, which have the features of anteroom(i), hilani(iii), I/L-shaped corridors(iv), elongated shrine(v), and enclosed courtyard(viii). In particular, it is not hard to understand that the type III has compositional elements in common with the type IV because they all came from early vernacular houses with elongated plans(v) and I and L-shaped corridors(iv), courtyards in Central Asia and Near East, in comparison with such other types as I and II. Indeed, notable is that the cases from the type I to the type IV commonly accept the hilani front (iii) and iwan hall(vi), originated from Nabataean and Achaemenid monuments, respectively. Lastly, responding to Table 2, the type $\mathrm{V}$ of square shrines occurred in the combination of the type I, and showed the feature of the fourcolumned hall of fire temples. On the contrary, the fire temple also adopted the court and portico unit of the inverted ' $U$ ' of the living quarters in residences of Central Asian regions plus the hilani front(iii) and distyle in antis(ii), albeit Buddhist monasteries of the territory did not adopt the vernacular methods.

\section{CONCLUSION}

It should be noted that organized religion and its rituals were regarded as pools of social cohesion that enabled to reduce conflicts between individuals in society. When the Buddhism was introduced in Central Asia, thus, the building methods of construction and the notions of entire layouts were dependent on early residences, palaces, and temples in Nabataean and Parthian Near East, Bactrian Central Asia as the means of social solidarity. As Schaefer pointed out, "it appears that in the last two centuries before Christ a considerable trade was carried on between India and Rome, but the regions that actually established the contact were Syria and Egypt"(Herwin Schaefer,1942:67). In like manner, Paul Bernard concluded the constructions of Ay Khanum "drew their inspiration largely from the Neo-Babylonian and Achaemenid models," albeit he believed that Greek builders participated in making the city (Paul Bernard, 1994:107).

Likewise, the square shrines of Buddhist temples in Central Asia, as discussed so far, were established through the selective application of the construction methods and compositional elements employed in the pre-Buddhist period or the Buddhist period, which came from Bactrian Central Asia, Nabataean Syria, Parthian Iran, and Gandhara (Table 1). In particular, the Buddhist temples followed the architectural composition of early houses in Central Asia such as anteroom(i), hilani front(iii), I/L-shaped passages(iv), iwan(vi), and enclosed courtyard(viii). Indeed, the shape of these temples in Central Asian Buddhism delivered the building methods of Nabataean temples such as anteroom(i), distyle in antis(ii), the hilani front(iii), elongated plan(v), and colonnaded passages(vii) as above-discussed through temples of Kasr Il-Abd and Baal Shamin. The Buddhist square shrines in Central Asia then were completed in the adoptions of anteroom(i), distyle in antis(ii), the hilani front(iii), I/L-shaped corridor(iv), elongated plan(v), and enclosed courtyard(viii).

Accordingly, this study concludes that the Buddhist square shrines in Central Asia primarily adopted anteroom(i), hilani(iii), I/L-shaped passages(iv), elongated hall(v), iwan(vi), 
and courtyard(viii). Additionally, this thesis confirms that the compositional elements in the Buddhist monument of Central Asia were applied according to local choices and ritual purposes because they, in comparison with other religious temples (particularly Zoroastrian temples), handled with different adoptions for their constructions such as a four-columned shrine $(\mathrm{V})$ and single-celled shrine(III) with a central altar respectively, albeit they all used vernacular methods for the constructions in the same territory (See Table 1 and 2). Consequently, the monasteries were represented as a cosmopolitan complex by both the adoption of vernacular building forms and the adaptation of universal notions for the Buddhist construction.

\section{REFERENCES}

Allchin, F.R. and N. Hammond (1978) The Archaeology of Afghanistan, Academic Press.

Andrae, W.and H. Lenzen(1933) "Die Partherstadt Assur," Wissenschaftliche Verbifentlichung der Deutschen OrientGesellschaft 57, Leipzig.

Baumer, Christoph (1998) "Dandan Oilik Revisited: New Findings a Century Later," Oriental Art, Volume 45 Number 2.

Behrendt, Kurt A. (2004) the Buddhist Architecture of Gandhara, Brill Academic Publishers.

Brown, Percy (1959) Indian Architecture: Buddhist and Hindu periods, Bombay: Taraporevala Sons.

Colledge, Malcolm A. R. (1967) The Parthians, Praeger.

Dinsmoor, William Bell (1950) the Architecture of Ancient Greece: an Account of its Historic Development, Batsford Ltd.

Erdmann, K. (1941) Das Iranische Feuergeiligtum, Leipzig.

Fogelin, Lars (2003) "Ritual and Presentation in Early Buddhist Religious Architecture," Asian Perspectives 42(1): 129-154.

Oelmann, Franz (1921) Persische Tempel, Archaeologischer Anzeiger 36.

Ghirshman, Roman (1962) Iran: Parthians and Sassanains, Thames and Hudson.

Goffman, E. (1959) The Presentation of Self in Everyday life, New York: Doubleday.

Goldman, Hetty (1931) Excavations at Eutresis in Boeotia, Cambridge Mass.: Harvard University Press.

Hanfmann, G.M.A. (1975) Roman Art, New York and London.

Herzfeld, Ernst (1935) Archaeological history of Iran, London: Oxford university press.

Ho, Puay-peng (1992) "Cave-Temple Pillar Symbolism," Sacred Architecture, Edinburgh University Press.

I-Tsing (2005) A record of the Buddhist religion as practiced in India and the Malay Archipelago (A.D. 671-695), AES.

Iwai, Shumpei 岩井俊本(2006)“アフガニスタンおよび周辺地域の 仏教寺院の変遷”, 仏教芸術289: 100-112.

Kato, Kyuzo 加藤九祚(1992) “中央アジアの仏教と遺跡”, 仏教芸術 205: 15-66.

Kim, Young Jae (2011) Architectural Representation of the Pure Land: Constructing the Cosmopolitan Temple Complex from Nagarjunakonda to Bulguksa, PhD diss., University of Pennsylvania.

Klimburg-Salter, Deborah (1989) the Kingdom of Bamiyan: Buddhist Art and Culture of the Hindu Kush, Napes - Rome.

Koldewey, R. (1898) Ausgrabungen in Sendschirli II, Mitteilungen aus den Orientalischen Sammlungen, 12. 186.

Kuwayama, Shoshin 桑山正進(1978) “ストゥーパ方形基台の由来, ”
足利惊氏博士喜寿記念 オリエント学インド学論集, 国書刊 行合: 197-212.

Kuwayama, Shoshin 桑山正進(1998) “アウグストゥス靈廟と大ス トゥーパ-車輪状構造の由來”, 東方學報 70: 506-566.

Lawrence, A.W. (1957) Greek Architecture, Penguin Books.

Litvinskii, B. A.(1994) "The Hellenistic Architecture and Art of the Temple of the Oxus," Bulletin of the Asian Institute, Vol 8.

Litvinskii, Boris Anatol' evich and Tamara Ivanovna Zeìmal (1971) Adzhina-Тера, Искусство.

Maillard, Monique (1983) Grottes et monuments d'Asie centrale J. Maisonneuve.

Marshall, Sir John Hubert (1921) Excavations at Taxila: the stupas and monasteries at Jauliāñ , Indological Book Corp.

Meister, Michael W. (1979) "Mandala and Practice in Nagara Architecture in North India," Journal of the American Oriental Society, Vol. 99, No. 2: 204-219.

Müller, Valentin(1944) "Development of the 'Megaron' in Prehistoric Greece,"American Journal of Archaeology 48, 4: 342-348.

Nagaraju, S. (1981) Buddhist Architecture of Western India, c. 250 B.C.A.D. 300, Delhi: Agam Kala Prakashan.

Ning, Qiang (2004) Art, Religion, and Politics in Medieval China: the Dunhuang cave of the Zhai Family, Univ. of Hawaii Press.

Reuther, Oscar (1938) "Parthian Architecture," a Survey of Persian Art: 411-44.

Paipakov, K. M. (1995) "Silk Road and Spread of Religions in Kazakhstan”, Jonggyo-wa munhwa, vol.1: 179-194.

Puchstein, O. (1892) "Die Säule in der Assyrischen Architektur," Jahrbuch des Archäologischen Instituts, 7: 1-24.

Pugachenkova, Galina A.(1991/1992) "the Buddhist Monuments of Airtam," S.R.A.A. II.

Rapoport, IU. A. (1996) "The Palaces of Topraq-Qala," Bulletin of the Asian Institute Vol 8.

Rowland, Benjamin (1974) The Art of Central Asia, Crown.

Sastri, N. (1966) The Satavahanas and their successors, in a History of South India: From Prehistoric Times to the Fall of Vijayanagar, Delhi: Oxford University Press.

Scerrato, U. (1977) "Evidence of Religious Life at Dahan-I Ghulaman, Sistan," South Asian Archaeology.

Schaefer, Herwin (1942) "Two Gandhäran Temples and Their near Eastern Sources," Journal of the American Oriental Society 62,1: 61-67.

Schlumberger, Daniel (1952) "Le temple de Surkh Kotal en Bactriane," Journal Asiatique 243: 433-453.

Schopen, G. (1997) Bones, Stones, and Buddhist Monks: Collected Papers on the Archaeology, Epigraphy, and Texts of Monastic Buddhism in India. Honolulu: University of Hawaii Press.

Settegast, Mary (1986) Plato Rehistorian: 10,000 to 5,000 BC Myth, Religion, Archaeology, Lindesfarne Press.

Smith, Earl Baldwin (1938) Egyptian Architecture, New York.

Stein, Aurel M. (1921) Serindia: Detailed report of explorations in Central Asia and westernmost China, Clarendon Press.

Stronach, D. (1985) "On the Evolution of the Early Iranian Fire Temple," in Papers in Honor of Professor Mary Boyce, Acta Iranica 25: 605-27.

Kramrisch, Stella (1946) the Hindu Temple, University of Calcutta.

de Villard, Ugo Monneret (1938) "the Iranian Temple of Taxila," A Survey of Persian Art, 1. 445.

Bernard, Paul and UNESCO(1994) History Of Civilizations Of Central Asia: the Development of Sedentary and Nomadic Civilization, volume 2 . 
Table 2. The five types of Buddhist temples in Central Asia and its neighboring areas, vis-à-vis eight elements for the constructions

\begin{tabular}{|c|c|c|c|c|c|c|c|c|c|c|c|c|c|c|}
\hline Sites / Types & DATE & $\mathbf{I}$ & II & III & IV & $\mathbf{V}$ & $\mathrm{i}$ & ii & iii & iv & $\mathrm{V}$ & vi & vii & viii \\
\hline \multicolumn{2}{|c|}{$\begin{array}{l}\text { Five types in square plans } \\
\text { in Buddhist monasteries } \rightarrow\end{array}$} & & & & & $\because$ & \multicolumn{8}{|c|}{$\begin{array}{l}\text { Eight elements for the composition of Buddhist monaster- } \\
\text { ies in Central Asia, vis-à-vis its neighboring areas }\end{array}$} \\
\hline \multicolumn{15}{|c|}{ Early Syria Houses in Near East } \\
\hline Halafian & 60c. BCE & & & & - & & - & ---- & ----- & $-\cdots$ & - & & & \\
\hline Arpachiyah & 27c. BCE & & & & $\bullet$ & & $\bullet$ & 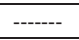 & 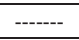 & 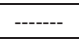 & $\bullet$ & & & \\
\hline Ain Ghazal & $72 / 55 \mathrm{BCE}$ & & & & & - & - & - & & & & & & \\
\hline Palace at Hatra & 1c. CE & - & & & & & - & - & - & - & - & - & ----- & - \\
\hline \multicolumn{15}{|c|}{ Early Houses in Anatolia/Greek } \\
\hline Megaron, Mycenae & 15-12c. BCE & & & & $\mathbf{\theta}==$ & $===0$ & $\bullet$ & $\bullet$ & 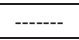 & $\begin{array}{ll}-\cdots--- \\
-\cdots\end{array}$ & $\bullet$ & & & \\
\hline Houses, Minor Asia & 15-12c. BCE & & & & - & & - & -..-- & -..-- & -..-- & - & & & \\
\hline \multicolumn{15}{|c|}{ Early Houses in Central Asia } \\
\hline Houses, Dilberjin & & $\bullet===$ & $=======$ & $======$ & $==\bullet$ & & - & $-\cdots$ & - & - & 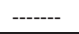 & - & ----- & - \\
\hline Ay Khanum & 4c. BCE & $\boldsymbol{\theta}====$ & $=======$ & $=======$ & $===0$ & & $\bullet$ & $\bullet$ & $\bullet$ & $\bullet$ & $\bullet$ & $\bullet$ & $\bullet$ & $\bullet$ \\
\hline \multicolumn{15}{|c|}{ Nabataean temples in Near East } \\
\hline Ba'al Shamin, Syria & 1c. CE & & & & & - & - & - & - & (----- & 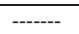 & ----- & -ב-ב- & - \\
\hline Kasr Il-Abd, Syria & 2c. BCE & & & & - & & - & - & - & (----- & - & ----- & - & \\
\hline Edfu Temple, Egypt & 3-1c. BCE & - & & & & & - & -...-- & --.--- & --.--- & - & -..---.- & - & \\
\hline \multicolumn{15}{|c|}{ Zoroastrian temples in Central Asia } \\
\hline Surkh Kotal & 1-2c. CE & $\boldsymbol{O}===$ & $=======$ & $=======$ & $===\mathbf{O}===$ & $===$ & $\bullet$ & $\begin{array}{ll}-\cdots--- \\
--1\end{array}$ & $\bullet$ & 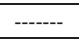 & 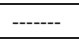 & (----- & $\begin{array}{l}----- \\
\end{array}$ & $\bullet$ \\
\hline Oxus temple & 2c. BCE & $\bullet===$ & $======$ & $=====$ & $=====$ & $==\bullet$ & - & $\bullet$ & - & $\bullet$ & - & & & \\
\hline Kuh-i-Khawaja, Iran & 1c. CE & & & & & 0 & $\bullet$ & $\bullet$ & $\bullet$ & $\bullet$ & & & & \\
\hline Jandial temple & 2-1c. BCE & & & & - & & - & - & - & - & - & ב----- & - & \\
\hline Susa temple & 5-4c. BCE & $\varphi===$ & $======$ & $======$ & $=====$ & $\bullet$ & $\bullet$ & $\bullet$ & $\bullet$ & $\bullet$ & $\bullet$ & 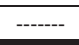 & - & 0 \\
\hline \multicolumn{7}{|c|}{ Buddhist Monasteries in Central Asia } & \multicolumn{8}{|c|}{$\begin{array}{l}\text { Eight elements for the composition of Buddhist monas- } \\
\text { teries in Central Asia }\end{array}$} \\
\hline Fayaz Tapa & 1c. BCE & & & & $\bullet$ & & $\bullet$ & +---- & 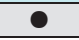 & $\bullet$ & $\begin{array}{ll}----- \\
\end{array}$ & 0 & $\bullet$ & $\bullet$ \\
\hline Guldara(Gurudara) & 4-6c. CE & & & & $\bullet$ & & 0 & +---- & +--- & $\bullet$ & $\begin{array}{l}----- \\
--1\end{array}$ & - ---- & ----- & 0 \\
\hline Kara Tepe & 4-5c. CE & $0==$ & $=======$ & $==$ & & & & & $\bullet$ & $\bullet$ & 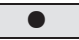 & (----- & 0 & $\bullet$ \\
\hline Tapa Sardar & 4-6c. CE & & & & $\bullet$ & & - & & & & & & & \\
\hline Dal'verzin-tepe & 4-6c. CE & & & $\bullet$ & & & $\bullet$ & $\begin{array}{l}----- \\
\end{array}$ & $\begin{array}{l}----- \\
\end{array}$ & $\begin{array}{l}----- \\
\end{array}$ & 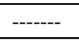 & $\bullet$ & & \\
\hline Adzina Tepe & 4-6c. CE & & & $0=$ & $======$ & $===$ & $\bullet$ & ----- & -ב--- & 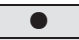 & - & $\bullet$ & 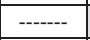 & $\bullet$ \\
\hline Airtam I & 4-6c. CE & $\boldsymbol{O}===$ & $========$ & $======$ & $======$ & $==0$ & $\bullet$ & 0 & 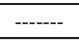 & $\bullet$ & & & & \\
\hline Airtam II & 4-6c. CE & & $0=$ & $======$ & $==0$ & & $\bullet$ & (----- & $\bullet$ & 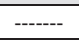 & $\bullet$ & $\bullet$ & & \\
\hline Ak-Beshim I & 6-7c. CE & & $\bullet$ & & & & $\bullet$ & $\bullet$ & $\bullet$ & +---- & $\bullet$ & $\bullet$ & ----- & $\bullet$ \\
\hline Ak-Beshim II & 6-7c. CE & $\bullet$ & & & & & $\bullet$ & +---- & -.--- & $\bullet$ & $\bullet$ & $\bullet$ & & \\
\hline Krasnorechensk I & 8-9c. CE & & $\bullet$ & & & & $\bullet$ & +---- & -ב--- & - & $\begin{array}{ll}-\cdots--- \\
\end{array}$ & $\bullet$ & & \\
\hline Krasnorechensk II & 8-9c. CE & & $\bullet$ & & & & 0 & $\begin{array}{l}-\cdots--- \\
\end{array}$ & $\begin{array}{l}----- \\
\end{array}$ & $\begin{array}{l}-\cdots--- \\
\end{array}$ & $\begin{array}{l}----- \\
\end{array}$ & $\bullet$ & & \\
\hline Karadong, n.61 & 4c. CE & & $\bullet$ & & & & & & & & & & & \\
\hline Dadan Oilik, D12 & 5-6c. CE & $0==$ & $==\bullet$ & & & & $\bullet$ & & & & & & & \\
\hline Kizil n.38 cave & 4c. CE & & & $\bullet$ & & & & & & & 0 & & & \\
\hline Shorchuk F4 & 5-6c. CE & $\bullet$ & & & & & $\bullet$ & & & & & & & \\
\hline Toqquz Sarai, A & 4-5c. CE & & & $\bullet$ & & & & & & & $\bullet$ & $\bullet$ & -ב-י- & $\bullet$ \\
\hline Bezeklik Temple 9 & 5-6c. CE & & $\bullet$ & & & & $\bullet$ & $\begin{array}{l}---- \\
--1\end{array}$ & $\bullet$ & $\begin{array}{l}----- \\
\end{array}$ & $\bullet$ & $\bullet$ & & \\
\hline \multicolumn{15}{|c|}{ "Gandharan Buddhist Monasteries in N. India/S. Pakistan } \\
\hline Butkara, GB & 2c. CE & - & & & & & $\bullet$ & (----- & $\bullet$ & & & & & \\
\hline Mohra, Taxila & 2c. CE & $\bullet=$ & $=======$ & $======$ & $=====$ & $=\bullet$ & $\bullet$ & - & $\bullet$ & ------ & $\bullet$ & & & \\
\hline Kalawan, A5 & 2c. CE & $\bullet$ & & & & & $\bullet$ & -1---- & ------ & ------ & $\bullet$ & & & \\
\hline Dharmarajika, $\mathrm{H}$ & 2c. CE & $\bullet$ & & & & & $\bullet$ & ------ & - & & & & & \\
\hline Ellora $n .10$ cave & 6-7c. CE & & & $\bullet$ & & & $\bullet$ & - & $\bullet$ & -ב--- & $\bullet$ & (----- & $\bullet$ & \\
\hline \multicolumn{15}{|c|}{ Hindu temples in India } \\
\hline Temple 17, Sanchi & 5-6c. CE & & & - & & & - & - & (-ב- & (-- & - & & & \\
\hline Ladh Khan & 5c. CE & & $\bullet$ & & & & $\bullet$ & $\bullet$ & -.---- & -.---- & $\bullet$ & & & \\
\hline \multicolumn{5}{|c|}{$\begin{array}{l}\text { I. SQUARE SHRINE SURROUNDED BY CIRCUMAMBULATION } \\
\text { PASSAGES / OUTER ENCLOSURE WALLS } \\
\text { II. SQUARE SHRINE WITH A CENTRAL ALTAR SURROUNDED BY } \\
\text { CIRCUMAMBULATION PASSAGES/OUTER ENCLOSURE WALLS } \\
\text { III. SINGLE-CELLED SQUARE SHRINE WITH A CENTRAL ALTAR } \\
\text { IV. SINGLE-CELLED SQUARE SHINE } \\
\text { V. FOUR-COLUMNED SQUARE SHRINE }\end{array}$} & \multicolumn{4}{|c|}{$\begin{array}{l}\text { i. ANTEROOMS } \\
\text { ii. DISTYLE IN ANTIS } \\
\text { iii. HILANI(small rooms on both sides) } \\
\text { iv. I or L-SHAPED CORRIDOR } \\
\text { v. ELONGATED HALL } \\
\text { vi. IWAN }\end{array}$} & \multicolumn{6}{|c|}{$\begin{array}{l}\text { vii. COLONNADE } \\
\text { viii. ENCLOSED COURTYARD (front/center) } \\
----\quad \text { combination of each element }(\bullet) \\
==- \text { combination of each plan type }(\bullet) \\
\text { grey: major elements that consist of temples }\end{array}$} \\
\hline
\end{tabular}

Valmin, Mattias Natan (1939) Das Adriatische Gebiet in Vor- und Frühbronzezeit, Lunds universitets.

Wachtsmuth, F. (1929) Der Raum 1. 76, Marburg.

Warner, Jayne. L. (1979) "The Megaron and Apsidal House in Early Bronze

Age Western Anatolia,"AJA83:133-147.

Weidhaas, Hermann (1939) Der bit hilani, Zeitschrift für Assyriologie,

Neue Folge 11.130.

Wood, Frances (2002) The Silk Road: two thousand years in the heart of
Asia, University of California Press.

Wright, James (1982) "The Old Temple Terrace at the Argive Heraeum and the Early Cult of Hera in the Argolid," The Journal of Hellenic Studies, Vol. 102

Rapin, Claude (1992) "Les Sanctuaires de l'Asie Centrale à l'époque hellénistique. Etat de la question", Etudes de Lettres, № 4, Lausanne 101-124.

(Date of Submission : 2005.12.2) 